\title{
Cadmium Removal by Two Strains of Desmodesmus pleiomorphus Cells
}

\author{
Cristina M. Monteiro • Paula M. L. Castro • \\ F. Xavier Malcata
}

C. M. Monteiro - P. M. L. Castro - F.X.Malcata

$\mathrm{CBQF} /$ Escola Superior de Biotecnologia,

Universidade Católica Portuguesa,

Rua Dr. António Bernardino de Almeida,

4200-072 Porto, Portugal

e-mail: fxmalcata@esb.ucp.pt

Keywords Microalgae · Heavy metals · Biosorption · $\mathrm{pH} \cdot$ Inactive biomass

Introduction

\begin{abstract}
The capacity of microalgae to accumulate heavy metals has been widely investigated for its potential applications in wastewater (bio)treatment. In this study, the ability of Desmodesmus pleiomorphus (strain L), a wild strain isolated from a polluted environment, to remove $\mathrm{Cd}$ from aqueous solutions was studied, by exposing its biomass to several $\mathrm{Cd}$ concentrations. Removal from solution reached a maximum of $61.2 \mathrm{mg} \mathrm{Cd} \mathrm{g}^{-1}$ biomass by 1 day, at the highest initial supernatant concentration used (i.e., $5.0 \mathrm{mg} \mathrm{Cd} \mathrm{L}{ }^{-1}$ ), with most metal being adsorbed onto the cell surface. Metal removal by D. pleiomorphus (strain ACOI 561), a commercially available ecotype, was also assessed for comparative purposes; a removal of $76.4 \mathrm{mg} \mathrm{Cd} \mathrm{g}^{-1}$ biomass was attained by 1 day for the same initial metal concentration. Assays for metal removal using thermally inactivated cells were also performed; the maximum removal extent observed was $47.1 \mathrm{mg} \mathrm{Cd} \mathrm{g}^{-1}$ biomass, at the initial

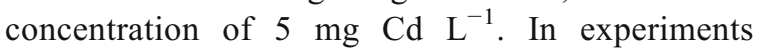
conducted at various $\mathrm{pH}$ values, the highest removal was achieved at $\mathrm{pH}$ 4.0. Both microalga strains proved their feasibility as biotechnological tools to remove $\mathrm{Cd}$ from aqueous solution.
\end{abstract}

The presence of heavy metals in aquatic ecosystems is a situation of major environmental concern, because they are essentially indestructible and difficult to remove (Yoshida et al. 2006), while being harmful to a variety of living species including human beings (Gupta and Rastogi 2008). Cadmium, one of the most toxic heavy metals commonly found in contaminated ecosystems, is frequently considered as a nonessential element for living organisms (Leborans and Novillo 1996; Tukaj et al. 2007). However, Lee and Morel (1995) have demonstrated that Cd can act as a nutrient of certain microalga species, including a significant enhancement of growth of $\mathrm{Zn}$-limited cultures of Thalassiosira weissflogii, Pleurochrysis carterae, and Tetraselmis maculate, provided that it exists at sufficiently low concentrations. In addition, Price and Morel (1990) reported that, in sea water containing a low $\mathrm{Zn}$ concentration, $\mathrm{Cd}$ stimulates growth of $T$. weissflogii, and claimed that the reason therefor was that $\mathrm{Cd}$ can substitute $\mathrm{Zn}$ in certain macromolecules. The major vehicles of release of this metal into aquatic environments are effluents of electroplating, dyeing, plastic, battery, and refining industrial processes (Gupta and Rastogi 2008; Özer et al. 1999; Pérez-Rama et al. 2002). Cadmium has been claimed 
to accumulate in higher animals, and thus cause renal disturbances, lung insufficiency, bone lesions, and even cancer (Gupta and Rastogi 2008; Özer et al. 1999).

The classical physico-chemical methods employed to remove toxic metals, viz. precipitation, evaporation, ion exchange, and oxidation/reduction (Aksu 2001; Gupta and Rastogi 2008), pose severe constraints associated with high capital and operating costs, in addition to generating several by-products (Aksu 2001). Therefore, development of more economically feasible techniques to remove this metal from the environment is in order. One possibility is biosorption, which takes advantage of the ability of biological materials, including microalgae, to remove heavy metals from waste streams (Gupta and Rastogi 2008; Yoshida et al. 2006).

Microalgae play, in general, a key role in aquatic environments, since they constitute the first step in the food chain - and are accordingly able to transfer metals up to higher trophic levels (Leborans and Novillo 1996; Moreno-Garrido 2008). Their application in environmental biotechnology has been increasingly exploited in recent years, owing, e.g., to their outstanding accumulation capacity of toxic metals from polluted waters, even at low supernatant concentrations, which facilitates removal thereof at lower costs via physicochemical methods (Gong et al. 2005; Moreno-Garrido 2008; Singh and Prasad 2000).

The aim of the present study was to assess the $\mathrm{Cd}$ removal capacity, by both living and inactivated cells, of a wild strain of the freshwater microalga Desmodesmus pleiomorphus that had been previously isolated from a heavy metal-polluted region in Northern Portugal (which will hereafter be labeled as L). Furthermore, the removal capacity of living cells of a commercial registered ecotype of D. pleiomorphus (ACOI 561) was also considered. The aforementioned site has for long been contaminated with heavy metals, e.g., $\mathrm{Pb}$ (ca. $835 \mathrm{mg} \mathrm{Pb} \mathrm{kg}^{-1}$ ), $\mathrm{Hg}$ (ca. $66 \mathrm{mg} \mathrm{Hg} \mathrm{kg}^{-1}$ ), and $\mathrm{Zn}$ (ca. $3620 \mathrm{mg} \mathrm{Zn} \mathrm{kg}^{-1}$ ), and $\mathrm{Cd}$ to a much lower extent (Oliveira et al. 2001).

\section{Materials and methods}

Microalga culture conditions

The unicellular freshwater green microalga $D$. pleiomorphus (L) was obtained from a heavy metal- polluted site in Northern Portugal (Oliveira et al. 2001), by enrichment, using culture media supplemented with the toxic metal of interest, whereas D. pleiomorphus (ACOI 561) was obtained from Coimbra Culture Collection of Algae (ACOI, Portugal).

Both microalgal cultures were cultivated batchwise in Optimal Hematococcus Medium, OHM (Bishop and Senger 1971), without ethylenediaminetetracetic acid (EDTA), previously sterilized, and maintained at $25^{\circ} \mathrm{C}$ under continuous light at an irradiance of $29.18 \mu \mathrm{E} \mathrm{s}^{-1} \mathrm{~m}^{-2}$ provided by cool fluorescent lamps. After reaching the exponential growth phase, microalgal cells were collected from the growing culture with a micropipette and used as inoculum in the subsequent experiments. All materials and culture media used to carry out the experiments were sterilized prior to use via autoclaving at $121^{\circ} \mathrm{C}$ and $1 \mathrm{~atm}$ for $15 \mathrm{~min}$.

A cadmium stock solution was prepared by diluting $\mathrm{CdCl}_{2}$ in deionized water to a final concentration of $0.5 \mathrm{~g} \mathrm{Cd} \mathrm{L}^{-1}$. For each experiment, an appropriate volume of this stock solution was added in advance to the experimental medium, so as to obtain the desired final metal concentration. All glassware material was previously rinsed with nitric acid, and several times afterwards with deionized water prior to use so as to avoid any analytical interference.

Cell growth was determined by measuring optical density (OD) at $600 \mathrm{~nm}$, using a Shimadzu mini 1240 spectrophotometer (Japan), and subsequently converting to dry weight (DW) according to a previously prepared calibration curve; recall that relationships between OD and microalgal dry weight have been followed elsewhere (Schmitt et al. 2001; Scragg and Bonnet 2002; Yan and Pan 2002) for similar purposes.

Microalga growth and Cd removal by living cells

The metal removal capacity by both strains of D. pleiomorphus was determined in triplicate batch tests, by exposing $0.02 \mathrm{~g} \mathrm{~L}^{-1}$ of microalgal biomass to culture medium containing initial $\mathrm{Cd}$ concentrations of $0.5,1,2.5$, and $5 \mathrm{mg} \mathrm{L}{ }^{-1}$. From each flask, duplicate samples of $75 \mathrm{~mL}$ each were collected just before addition of the microalga biomass, and then daily for 7 days, to assay for biomass and Cd removal (as described below). Samples were centrifuged, and 
the supernatant was collected for analysis of $\mathrm{Cd}$ concentration. Subsequently, the pellet was washed with a 0.02 M EDTA solution for $20 \mathrm{~min}$ to remove $\mathrm{Cd}$ ions adsorbed onto the cell surface. A subsequent centrifugation was completed, and the pellet was digested overnight by acid treatment $(1 \mathrm{~mL}$ of $15 \mathrm{M}$ $\mathrm{HNO}_{3}+0.5 \mathrm{~mL}$ of $70 \% \mathrm{HClO}_{4}$ ) to determine the amount of intracellular $\mathrm{Cd}$ - according to the method described below. Experiments were run in triplicate.

Blank controls (containing only culture medium plus metal) were also carried out for each concentration tested, to confirm that the supernatant $\mathrm{Cd}$ concentration initially provided was not affected by any factor other than those conveyed by the microalgae during the timeframe of the experiments.

\section{Cd analysis}

The amount of Cd left in the supernatant and the amount incorporated into the cells were both analyzed in the samples via atomic absorption spectrophotometry with flame atomization (FA-AAS), in a Perkin Elmer 3100 (USA) spectrophotometer, according to the method by Matsunaga et al. (1999) and Pérez-Rama et al. (2002); the measuring threshold was $0.011 \mathrm{mg} \mathrm{Cd} / \mathrm{L}$.

The concentration of metal removed was calculated as follows: the total $\mathrm{Cd}$ removed by microalgal cells corresponded to the difference between the initial $\mathrm{Cd}$ concentration in the solution and the remaining $\mathrm{Cd}$ concentration in the supernatant, at each sampling time; and the amount of metal adsorbed onto the microalga cell surface was calculated as the difference between the total amount of $\mathrm{Cd}$ removed and the amount incorporated into the cells.

\section{Cd removal by inactivated cells}

To determine the removal capacity of inactivated cells of D. pleiomorphus (L), microalgal biomass harvested from a growing culture in the exponential phase was subjected to heating at $100^{\circ} \mathrm{C}$ for $24 \mathrm{~h}$. An aliquot of $0.02 \mathrm{~g} \mathrm{~L}^{-1}$ dry weight of inactivated microalgal biomass was then exposed to OHM medium, containing $\mathrm{Cd}$ at $0.5,1,2.5$, and $5 \mathrm{mg} \mathrm{L}^{-1}$. Experiments were run in triplicate.

Samples were collected at $0,5,15,30,60$, and $90 \mathrm{~min}$, and the supernatant was assayed for the residual metal concentration after centrifugation. The amount of total $\mathrm{Cd}$ removed was evaluated as described above for the viable biomass.

Cd removal at variable $\mathrm{pH}$

The extent of $\mathrm{Cd}$ removal was determined as a function of $\mathrm{pH}$, by exposing aliquots of $0.27 \mathrm{~g} \mathrm{~L}^{-1}$ of living microalgal biomass to $\mathrm{OHM}$ medium containing an initial $\mathrm{Cd}$ concentration of $2.5 \mathrm{mg} \mathrm{L}^{-1}$, at a $\mathrm{pH}$ previously adjusted to between 3.0 and 7.0 using $1 \mathrm{M} \mathrm{NaOH}$ or $1 \mathrm{M} \mathrm{HCl}$. Experiments were run in triplicate. At the end of the test, $\mathrm{pH}$ values were measured again - with no significant variation detected within the experimental timeframe.

Samples were collected at $0,5,15,30,45,60,90$, and $120 \mathrm{~min}$, and the supernatant was assayed for residual $\mathrm{Cd}$ concentration as described above.

\section{Statistical analyses}

The experimental data were subjected to statistical analysis using SPSS software, v. 16.0 (USA), via analysis of variance (ANOVA). Tukey's test was further applied to statistically pinpoint significant differences (at the 5\% level) between means. Statistical analysis of biomass data was done using normalized values, obtained by dividing biomass at each time by their initial counterpart.

\section{Results and discussion}

Cd adsorptioin and absorption by living cells

Assessment of the bioremoval capacity of the two strains of D. pleiomorphus (L and ACOI 561) included exposure of the microalgal cells, for 7 days, to media containing various initial $\mathrm{Cd}$ concentrations. Although $\mathrm{Cd}$ is not listed at the contaminated site as a major pollutant, this metal was chosen for this study as a model of toxic element to characterize the removal capacity of the wild microalgal cells. Even though the actual maximum removal level was attained within a few hours (or even minutes), following exposure of the microalgal cells, because adsorption dominatesand it is not connected to cell metabolism, exposure of said cells for a longer period was tested so as to assess their capacity to incorporate the toxic metal intracellularly. 
The growth curves associated with each microalga are shown in Fig. 1. Comparison of the growth rate of the two strains by the last day of exposure (via a Student's $t$ test) indicated that the L ecotype was significantly $(p<0.05)$ more tolerant at $0.5 \mathrm{mg} \mathrm{Cd} \mathrm{L}^{-1}$; for the other concentrations tested, no significant differences $(p>0.05)$ were detected in biomass density.

Additionally, one-way ANOVA indicated that growth decreased significantly $(p<0.05)$ with increasing $\mathrm{Cd}$ concentrations for both microalga strains; similar decreasing patterns over time were reported before by Carr et al. (1998), Costa and França (1998), and Torres et al. (1998), when Chlorella vulgaris (a freshwater microalga), Tetraselmis chuii (a seawater microalga), and Phaeodactylum tricornutum (a seawater microalga), respectively, were exposed to various initial $\mathrm{Cd}$ concentrations (1-160 $\mathrm{mg} \mathrm{L}^{-1}$ ). Two-way ANOVA was performed on data concerning growth of each ecotype vs. initial $\mathrm{Cd}$ concentration and incubation time; for the two strains, both factors (as well as their interactions) had a significant effect $(p<0.001)$ on biomass growth.

Both D. pleiomorphus strains were able to remove $\mathrm{Cd}$ via adsorption onto the cell surface, coupled with intracellular uptake. The total amounts of $\mathrm{Cd}$ removed, adsorbed, and incorporated by the cells of both ecotypes, as a function of exposure time and initial $\mathrm{Cd}$ concentration, are shown in Fig. 2. It can be noticed that the total amount of $\mathrm{Cd}$ removed by microalgae increased with increasing initial metal concentration.

For both microalga ecotypes, the total $\mathrm{Cd}$ removal underwent an initial fast uptake, with the maximum removal observed after 1 day of exposure, irrespective of the initial concentration considered (except the
Fig. 1 Growth of a Desmodesmus pleiomorphus (L) and b D. pleiomorphus (ACOI 561) throughout time, at various initial $\mathrm{Cd}$ concentrations. Results are expressed as means; error bars represent standard deviations $(n=3)$. For each contact time, columns labeled with different letters are significantly different from each other $(p<0.05)$. Biomass data refer to the ratio between biomass at each sampling stage and initial biomass
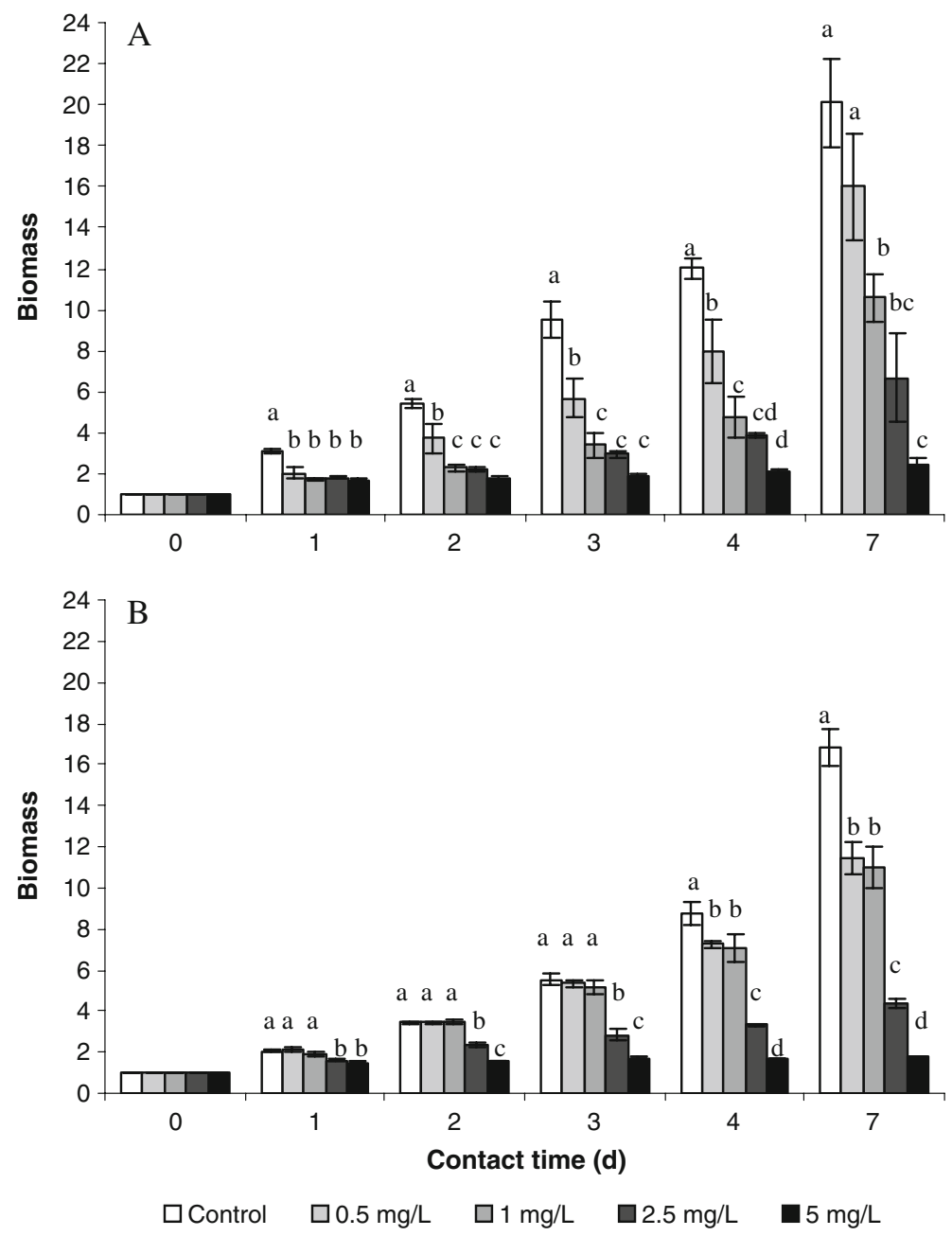

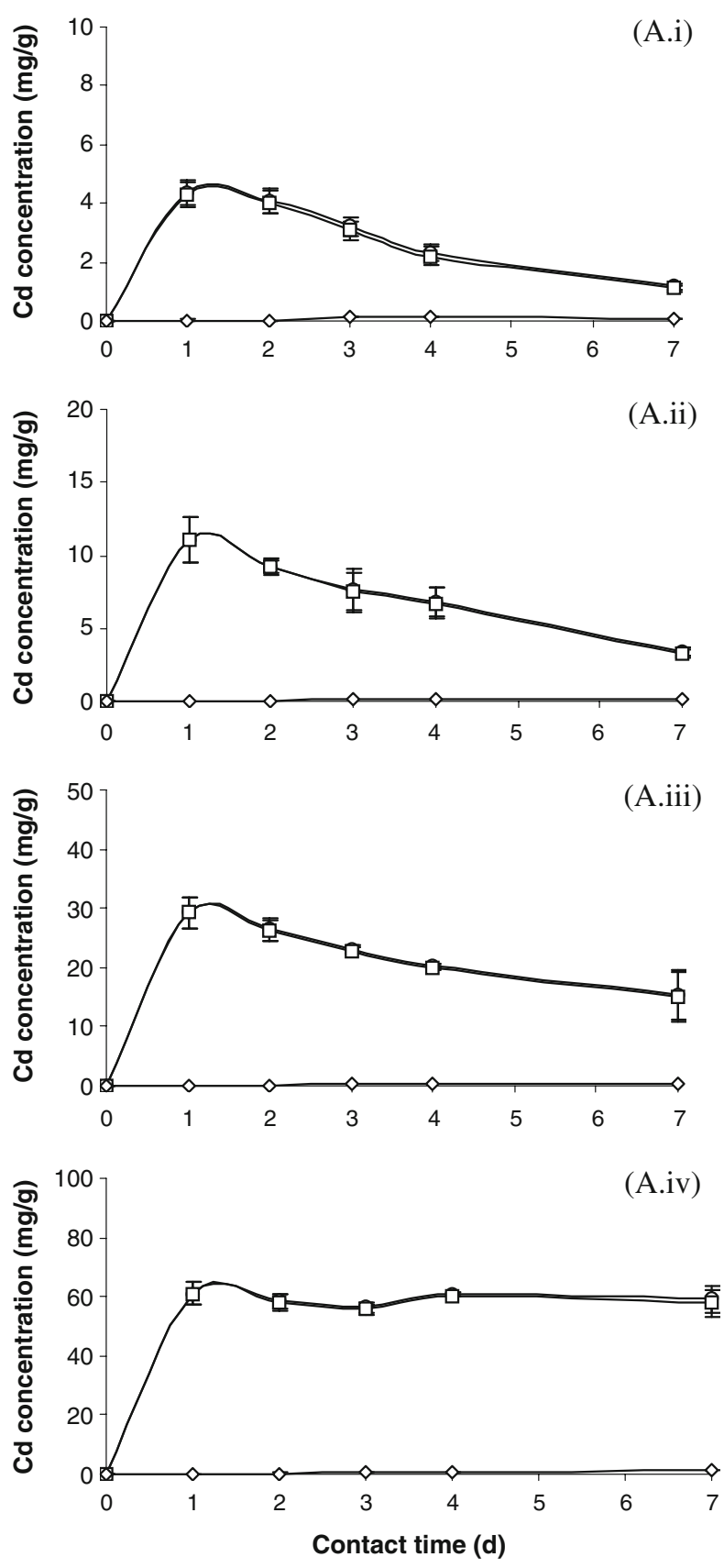

$\multimap-$ Total Cd removed $\multimap-C d$ adsorbed $\multimap-C d$ incorporated

Fig. 2 Total amounts of Cd removed, adsorbed, and incorporated by $(A)$ Desmodesmus pleiomorphus (L) and (B) Desmodesmus pleiomorphus (ACOI 561) throughout time, at various initial $\mathrm{Cd}$

commercial ecotype when exposed to the highest $\mathrm{Cd}$ concentration, which reached its maximum removal only by ca. 2 days). Afterwards, a consistent decline in the total Cd removal was observed.
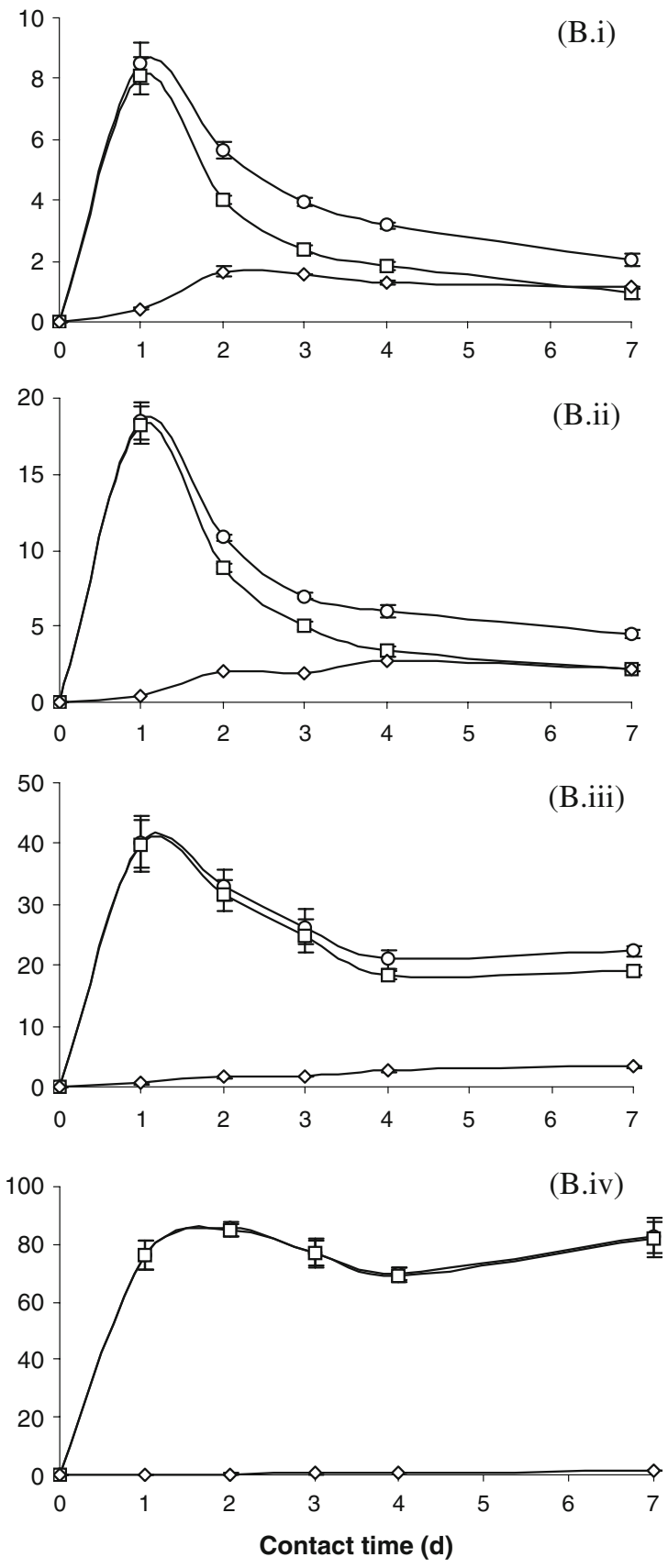

$\multimap$ - Total Cd removed $\multimap \square-C d$ adsorbed $\multimap-C d$ incorporated

concentrations: (i) 0.5, (ii) 1, (iii) 2.5, and (iv) $5 \mathrm{mg} / \mathrm{L}$. Results are expressed as means; error bars represent standard deviations $(n=3)$

On the other hand, Cd ions were mainly removed by adsorption onto the cell surface by both microalgaeexcept when D. pleiomorphus (ACOI 561) was exposed to the two lowest $\mathrm{Cd}$ concentrations tested; 
in this case, a considerable amount of $\mathrm{Cd}$ removed was accumulated intracellularly (Fig. 2B.i and B.ii). The aforementioned dominant pattern was observed right from start up of the experiment; by the last day of exposure, the amount of $\mathrm{Cd}$ accumulated intracellularly by $D$. pleiomorphus (ACOI 561), at $0.5 \mathrm{mg} \mathrm{Cd} \mathrm{L}^{-1}$ initial metal concentration, was higher than that adsorbed onto the cell surface (or reached similar amounts, as happened with $1 \mathrm{mg}$ $\mathrm{Cd} \mathrm{L}^{-1}$ ). Torres et al. (1998) have reported similar results at the lowest metal concentration tested: they described that, $25 \mathrm{mg} \mathrm{L}^{-1}$, intracellular $\mathrm{Cd}$ content was always higher than that adsorbed onto the cells; this realization was rationalized by the fact that $\mathrm{Cd}$ uptake by the cells is mainly an energydependent process since, at higher metal concentrations, toxicity of $\mathrm{Cd}$ to cells led to reduction of uptake thereof, with consequent decrease in degree of removal by incorporation. On the other hand, $\mathrm{Cd}$ removal, mainly by adsorption onto the cell surface, has been described elsewhere: Carr et al. (1998) claimed that the microalga cell wall acts so as to protect the intracellular micro-environment, via obstructing the inlet of metal into the cytoplasm in the first place; Sakaguchi et al. (1979) reported that the uptake of $\mathrm{Cd}$ by $C$. vulgaris was not mediated by any metabolic process, and thus was basically a surface phenomenon of adsorption; and Torres et al. (1998) also found a decline in intracellular $\mathrm{Cd}$ accumulation by $P$. tricornutum, at the higher concentrations tested $(25-100 \mathrm{mg} / \mathrm{L})$, probably due to the severe toxic effects of the metal on the microalga cells. Hence, metabolism-dependent uptake of metal ions appears not so relevant for this microalga.

For both cultures, the maximum amount of metal removal took place at the highest initial $\mathrm{Cd}$ concentration tested (i.e., $5 \mathrm{mg} \mathrm{L}^{-1}$ ) - thus leading to a total removal of 61.2 (i.e., $52.6 \%$ ) and $85.3 \mathrm{mg} \mathrm{Cd} \mathrm{g}^{-1}$ biomass (i.e., 53.9\%), for D. pleiomorphus (L) and (ACOI 561), respectively. Nonetheless, the highest percent removals, $98.8 \%$ and $98.1 \%$, were effected by D. pleiomorphus (L) and (ACOI 561), respectively, when exposed to $0.5 \mathrm{mg} \mathrm{Cd} \mathrm{L}{ }^{-1}$. Consistent results have previously been produced by Costa and Leite (1990), who detected a less effective percent removal at higher initial metal concentrations.

According to Student's t-tests, D. pleiomorphus (ACOI 561) yielded significantly $(p<0.05)$ higher total Cd removal levels when compared with its (L) counterpart - except by 3 and 4 days of exposure, at 1 and $2.5 \mathrm{mg} \mathrm{Cd} \mathrm{L}^{-1}$.

The degrees of total $\mathrm{Cd}$ removal obtained in this study are higher than those reported by a number of authors. Rangsayatorn et al. (2002) and Solisio et al. (2008) stated that Spirulina platensis sorbed 23.8 and $49 \mathrm{mg} \mathrm{Cd} \mathrm{g}{ }^{-1}$, respectively, whereas Tüzün et al. (2005) reported that Chlamydomonas reinhardtii could adsorb up to $42.6 \mathrm{mg} \mathrm{Cd} \mathrm{g}^{-1}$. Maeda et al. (1990) described, in turn, a maximum accumulation capacity of Cd by C. vulgaris of $18.0 \times 10^{4} \mu_{\mathrm{g} \mathrm{g}} \mathrm{g}^{-1}$, by

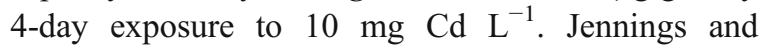
Rainbow (1979) tackled accumulation of $\mathrm{Cd}$ by Dunaliella tertiolecta for 5 days at several initial metal concentrations, and observed a rapid initial uptake, followed by a stabilization of the amounts of $\mathrm{Cd}$ adsorbed, reaching a maximum of $1.57 \mu \mathrm{g} \mathrm{mg}^{-1}$ at an initial concentration of $5.0 \mathrm{mg} \mathrm{L}^{-1}$. However, a previous study encompassing the same microalgal strains but exposed to $\mathrm{Zn}$ (which was present in the contaminated soil to relatively high levels) indicated an opposing trend-i.e., the wild strain removed higher amounts of the toxic metal from the culture medium, when compared with the commercial strain (Monteiro et al. 2009).

It is widely accepted that the capacity to remove metal ions from solution is both metal and microalga specific (Radway et al. 2001). However, uptake of metal ions is a two-step mechanism: an initial, rapid step followed by a later, slower one. In the former (sorption), metal ions are adsorbed by physical binding onto the surface of microalgal cells, whereas in the latter (intracellular uptake), metal ions are actually transported across the cell membrane into the cytoplasm (Matsunaga et al. 1999; Rangsayatorn et al. 2002). Costa and Leite (1990) observed that $\mathrm{Cd}$ removal by Chlorella homosphaera followed an essentially uniform profile over the range $0.5-$ $14.0 \mathrm{mg} / \mathrm{L}$, with a marked initial $\mathrm{Cd}$ retention followed by a slower retention. In general, adsorption of $\mathrm{Cd}$ ions onto the cell surface appears to be the dominant mechanism of metal removal by the two microalga ecotypes considered, although the commercial ecotype is apparently more efficient in doing so. Similar results have been reported by Sakaguchi et al. (1979), who claimed that most Cd removed by Chlorella regularis cells was via plain adsorption onto the cell surface (ca. 4,000 $\mu \mathrm{g} \mathrm{g}^{-1}$ ), thus being 
dependent upon local physico-chemical conditions encompassing the cell surface ligands. It has been claimed that microalgal species isolated from contaminated environments may exhibit higher tolerance and metal removal capacity than those grown in clean environments (Chong et al. 2000); however, this was not the case of our findings. This outcome could be related to the fact that $\mathrm{Cd}$ was not one of the major pollutants of the source environment of the strain isolated. Therefore, it may be presumed that the strains isolated from polluted locations can be more effective in removing (as well as tolerate higher levels of) toxic metals from solution than commercial strains only when such metals are already present in their natural environments.

\section{CD adsorption by inactivated cells}

A few studies available in the literature have shown that metal uptake by dead microalgae occurs through (rapid) adsorption, since this is a passive, nonmetabolic process that essentially takes place on the cell wall surface (Chu and Hashim 2004; Kaduková and Virčíková 2005; Sakaguchi et al. 1979).

As shown in Fig. 3, inactivated biomass underwent fast metal removal from solution, hence reaching its maximum within the first minutes of contact at all supernatant $\mathrm{Cd}$ concentrations tested. Other authors have shown a similar trend: Pawlik-Skowrońska et al. (1998) stated that $70 \%$ of the total Cd available in the supernatant did bind to Chlorella kessleri dead biomass within the first $15 \mathrm{~min}$ of contact; and Matheickal et al. (1999) revealed that $90 \%$ of the total soluble $\mathrm{Cd}$ was removed from solution by Durvillaea potatorum within $30 \mathrm{~min}$.

In our study, the extent of $\mathrm{Cd}$ removal by inactivated biomass by 90 min was higher at higher initial $\mathrm{Cd}$ concentrations, with a maximum attained at the highest $\mathrm{Cd}$ concentration tested (i.e., $47.1 \mathrm{mg} \mathrm{Cd}$ $\mathrm{g}^{-1}$, at $5 \mathrm{mg} \mathrm{Cd} \mathrm{L}^{-1}$ ) - as shown in Fig. 3. Following ANOVA of data pertaining to $\mathrm{Cd}$ removal vs. initial $\mathrm{Cd}$ concentration by the end of each experiment, a significant effect $(p<0.001)$ was found. The total

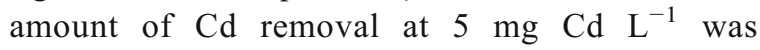
significantly $(p<0.05)$ higher than at the other concentrations considered; the degrees of $\mathrm{Cd}$ removal attained at the two lowest $\mathrm{Cd}$ concentrations $(0.5$ and $\left.1 \mathrm{mg} \mathrm{L}^{-1}\right)$ were not significantly $(p>0.05)$ different from each other, but both were significantly $(p<0.05)$ lower than those obtained at the other concentrations. Additionally, application of a Student's $t$-test to data pertaining to removal of $\mathrm{Cd}$ via adsorption by inactivated and living biomass indicated that: the former was significantly $(p<0.05)$ higher only at 0.5 and $2.5 \mathrm{mg} \mathrm{Cd} \mathrm{L}^{-1}$; at $1 \mathrm{mg} \mathrm{Cd} \mathrm{L}^{-1}$, no significant $(p>0.05)$ differences were detected; and at $5 \mathrm{mg} \mathrm{Cd}$ $\mathrm{L}^{-1}$, metal removal by adsorption was significantly $(p<0.05)$ lower. Reports available in the literature pertaining to metal removal capacity by dead and living microalgal cells point at different directions. A
Fig. 3 Total amount of $\mathrm{Cd}$ removed by non-viable Desmodesmus pleiomorphus (L) throughout time, at various initial Cd concentrations. Results are expressed as means; error bars represent standard deviations $(n=3)$

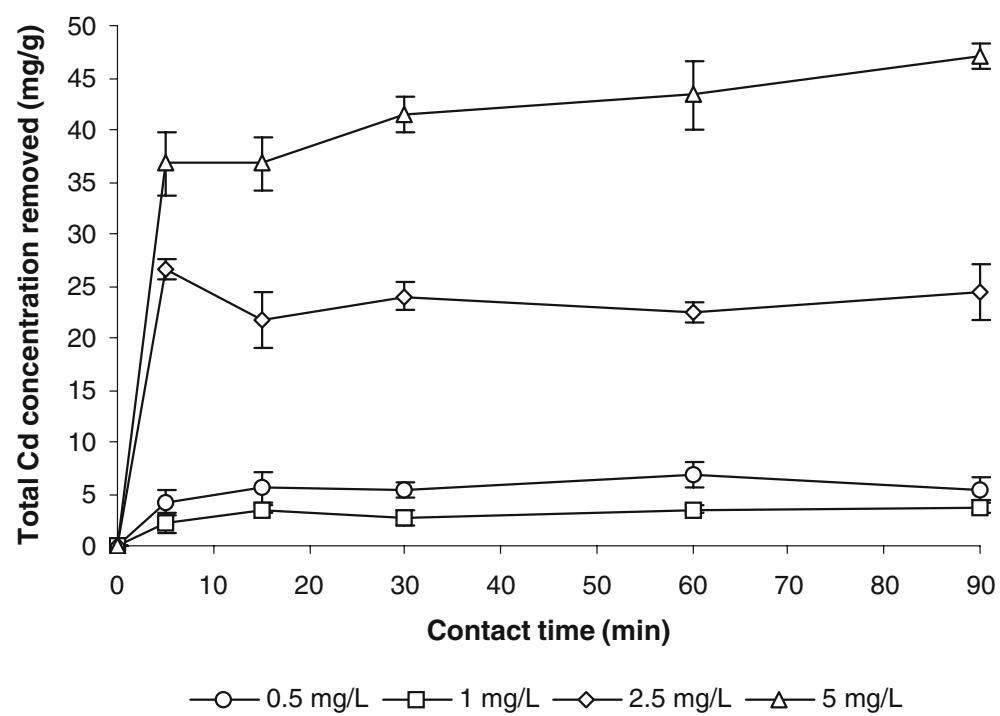


few studies demonstrated a lower capacity of the former to remove metal cations when compared to living cells, due to a putative disruption of the functional groups on the surface of their cell walls (Costa and França 1998). However, other authors have reported that thermally processed cells take up heavy metals to a greater extent than do living ones (Özer et al. 1999; Sakaguchi et al. 1979).

The maximum adsorption extents observed in our study were higher than those reported by Aksu (2001) with $C$. vulgaris, even when the $\mathrm{Cd}$ concentration employed was one fifth of that reported (i.e., $22.2 \mathrm{mg}$ $\mathrm{Cd} \mathrm{g}^{-1}$ ) upon exposure to $25 \mathrm{mg} \mathrm{Cd} \mathrm{L}^{-1}$.

In general, non-viable biomass is preferred for sorption processes, because it is not affected by toxicity of the metal ions, and is also more economical because stringent conditions for maintenance and growth (e.g., light, temperature, and nutrients) are no longer required. Moreover, it has been reported (Chu and Hashim 2004; Maeda and Sakaguchi 1990; Yan and Pan 2002) that dead biomass often displays a better metal binding capacity than living cells. Nevertheless, living biomass has the ability to remove toxic metals also via intracellular incorporation, a metabolic process that is obviously not possible for dead cells (Garnham et al. 1992). Finally, inactivated microorganisms were found more advantageous than living ones, because they can repeatedly be used as (bio)sorbents - as adsorbed metals can easily be recovered from the biomass they are bound to, via physical or chemical means (Chu and Hashim 2004). Although the biomass of several microorganisms has been used for heavy metal removal, activated carbon columns as adsorbent are an alternative; Ahn et al. (2009) focused on the capacity of activated carbon, impregnated with anionic surfactants, to adsorb $\mathrm{Cd}$ (II), and attained removals up to $0.198 \mathrm{mmol} \mathrm{g}^{-1}$ (or $22.26 \mathrm{mg} \mathrm{g}^{-1}$ ) - a value that was lower than ours.

In view of the above, adsorption via inactivated biomass of D. pleiomorphus (L) appears as well to be a valuable method for $\mathrm{Cd}$ removal from polluted waters.

\section{Cd removal at variable $\mathrm{pH}$}

Removal of heavy metals by microalgae is significantly affected by the $\mathrm{pH}$ of the medium (Ahuja et al. 1999; Chojnacka et al. 2005; Deng et al. 2007; Gong et al. 2005; Gupta et al. 2006; Sheng et al. 2007). The effect of $\mathrm{pH}$ on the biosorption capacity of $\mathrm{Cd}$ ions by D. pleiomorphus (L) is shown in Fig. 4; biosorption increased with $\mathrm{pH}$ up to 4.0 , and then declined with further increase in $\mathrm{pH}$.

The maximum biosorption observed was $2.3 \mathrm{mg}$ $\mathrm{Cd} \mathrm{g}^{-1}$ at $\mathrm{pH} 4.0$ - and the lowest one was $1.6 \mathrm{mg} \mathrm{Cd}$ $\mathrm{g}^{-1}$ at $\mathrm{pH}$ 3.0. This low binding capacity is consistent with earlier reports on microalgal biomass (Han et al. 2006; Rangsayatorn et al. 2002; Sánchez et al. 1999; Vannela and Verma 2006). Crist et al. (1981) suggested that a zero-point net charge (or isoelectric point) is found at $\mathrm{pH} 3$ for microalgae, above which microalgal cells bear a negative charge that will lead to electrostatic attraction between positively charged cations, such as $\mathrm{Cd}^{2+}$, and negatively charged binding sites; this might justify the rapid rise in binding efficiency when $\mathrm{pH}$ rises above 3.0. The decrease in $\mathrm{Cd}$ binding at $\mathrm{pH}$ values above 4.0 is likely due to complexation of those ions by $\mathrm{OH}^{-}$groups, which will prevent adsorption.

ANOVA was performed on the data pertaining to Cd removal vs. $\mathrm{pH}$ : $D$. pleiomorphus (L) biomass was significantly $(p<0.05)$ more efficient in removing $\mathrm{Cd}$ ions at $\mathrm{pH} \mathrm{4}$; and removal extents at the other $\mathrm{pH}$ values tested (i.e., 3, 5, 6, and 7) were not significantly $(p>0.05)$ different from each other.

Although the maximum sorption capacity reported in the literature is considerably higher than that observed in our study, similar findings were reported by Aksu (2001) in what concerns the $\mathrm{pH}$ dependence of removal: the sorption capacity of $\mathrm{Cd}$ by $C$. vulgaris was found to vary with $\mathrm{pH}$, and the maximum uptake

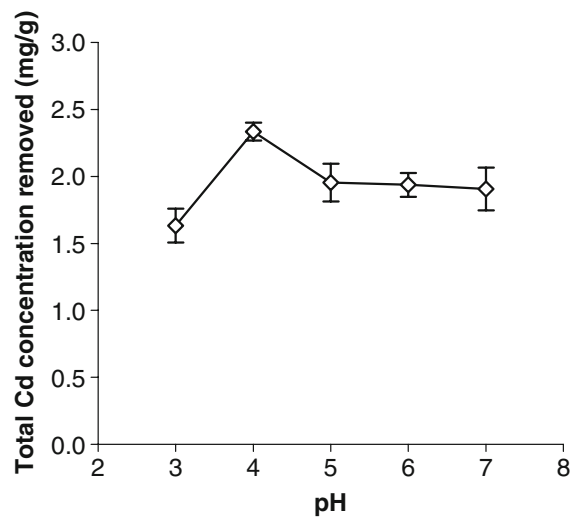

Fig. 4 Total amount of $\mathrm{Cd}$ removed by Desmodesmus pleiomorphus (L) by $120 \mathrm{~min}$, at various $\mathrm{pH}$ values, at an initial Cd concentration of $2.5 \mathrm{mg} / \mathrm{L}$. Results are expressed as means; error bars represent standard deviations $(n=3)$ 
attained was $62.3 \mathrm{mg} \mathrm{Cd} \mathrm{g}^{-1}$ at $\mathrm{pH}$ 4.0. Han et al. (2006) and Sánchez et al. (1999) also reported that the maximum sorption capacities of $\mathrm{Cr}^{3+}$ by Chlorella miniata and of $\mathrm{Cu}^{2+}$ by Cymodocea nodosa were 41.12 and $52.68 \mathrm{mg} \mathrm{g}^{-1}$, respectively, at $\mathrm{pH} 4.5$.

The dependence of metal biosorption on $\mathrm{pH}$ is related to both the functional groups on the surface of the microalgal cell walls and the metal chemistry prevailing in solution (Gong et al. 2005): an intermediate $\mathrm{pH}$ affects the solubility of the metals and the ionization state of the functional groups (viz. carboxylate, phosphate, and amino groups) on the cell wall of microalgae. At low $\mathrm{pH}$, the cell wall functional groups are closely associated with hydronium ions, and repulsion forces limit the approach of (positively charged) metal ions; as $\mathrm{pH}$ increases, more ligands (viz. amino and carboxyl groups) become exposed, so a more negative net charge will result that enhances adsorption (Bayramoğlu et al. 2006; Sheng et al. 2004).

Based on our experimental results, D. pleiomorphus (L) can be considered suitable for bioremediation of contaminated waters, especially when $\mathrm{pH}$ lies in the vicinity of 4.0 .

\section{Conclusions}

Both the wild and the commercial strains of D. pleiomorphus (i.e., L and ACOI 561) are able to remove $\mathrm{Cd}$ from aqueous solution-hence demonstrating the potential of either of those strains for bioremediation of metal-polluted waters or wastewaters. Both strains are apparently good biosorbents for $\mathrm{Cd}$ ions, with maximum removal extents of 61.2 and $85.3 \mathrm{mg} \mathrm{g}^{-1}$ by 1 day of exposure to $5 \mathrm{mg} \mathrm{Cd}$ $\mathrm{L}^{-1}$. Although some authors have claimed that microalgal biomass isolated from polluted environments is more tolerant and able to remove higher amounts of toxic metals from its surroundings, that statement did not fully hold in our experiments - probably because $\mathrm{Cd}$ was not a major contaminant in the natural environment from where the sediments were collected. The dominant mechanism of Cd removal is adsorption onto the cell surface. Hence, thermally inactivated cells were also able to remove $\mathrm{Cd}$ ions from solution, although to a lesser extent than living ones. It was also found that $\mathrm{pH}$ influences $\mathrm{Cd}$ removal, with a maximum uptake at ca. $\mathrm{pH} 4.0$.
Acknowledgements - The authors are grateful to Câmara Municipal de Estarreja (Portugal), for allowing full access to the contaminated site, and to Fundação para a Ciência e Tecnologia (Portugal) and Fundo Social Europeu (III Quadro Comunitário de Apoio, EC), for partial financial support of this work via a $\mathrm{PhD}$ fellowship granted to author C. M. Monteiro (ref. SFRH/BD/9332/ 2002), under the supervision of author F. X. Malcata.

\section{References}

Ahn, C. K., Park, D., Woo, S. H., \& Park, J. M. (2009). Removal of cationic heavy metal from aqueous solution by activated carbon impregnated with anionic surfactants. Journal of Hazardous Materials, 164, 1130-1136.

Ahuja, P., Gupta, R., \& Saxena, R. K. (1999). $\mathrm{Zn}^{2+}$ biosorption by Oscillatoria anguistissima. Process Biochemistry, 34, $77-85$.

Aksu, Z. (2001). Equilibrium and kinetic modelling of cadmium (II) biosorption by $C$. vulgaris in a batch system: effect of temperature. Separation and Purification Technology, 21, 285-294.

Bayramoğlu, G., Tuzun, I., Celik, G., Yilmaz, M., \& Arica, M. Y. (2006). Biosorption of mercury(II), cadmium(II) and lead(II) ions from aqueous system by microalgae Chlamydomonas reinhardtii immobilized in alginate beads. International Journal of Mineral Processing, 81, 35-43.

Bishop, N. I., \& Senger, H. (1971). Preparation and photosynthetic properties of synchronous cultures of Scenedesmus. In A. S. Pietro (Ed.), Methods in Enzymology (pp. 53-66). New York: Academic.

Carr, H. P., Cariño, F. A., Yang, M. S., \& Wong, M. H. (1998). Characterization of the cadmium-binding capacity of Chlorella vulgaris. Bulletin of Environmental Contamination and Toxicology, 60, 433-440.

Chojnacka, K., Chojnacki, A., \& Górecka, H. (2005). Biosorption of $\mathrm{Cr}^{3+}, \mathrm{Cd}^{2+}$, and $\mathrm{Cu}^{2+}$ ions by blue-green alga Spirulina sp.: kinetics, equilibrium and the mechanism of the process. Chemosphere, 59, 75-84.

Chong, A. M. Y., Wong, Y. S., \& Tam, N. F. Y. (2000). Performance of different microalgal species in removing nickel and zinc from industrial wastewater. Chemosphere, 41, 251-257.

Chu, K. H., \& Hashim, M. A. (2004). Quantitative analysis of copper biosorption by the microalga Chlorella vulgaris. Environmental Engineering Science, 21, 139-147.

Costa, A. C. A., \& França, F. P. (1998). The behaviour of the microalgae Tetraselmis chuii in cadmium-contaminated solutions. Aquaculture International, 6, 57-66.

Costa, A. C. A., \& Leite, S. F. G. (1990). Cadmium and zinc biosorption by Chlorella homosphaera. Biotechnology Letters, 12, 941-944.

Crist, R. H., Oberholser, K., Shank, N., \& Nguyen, M. (1981). Nature of bonding between metallic ions and algal cell walls. Environmental Science and Technology, 15, 1212-1217.

Deng, L., Zhu, X., Wang, X., Su, Y., \& Su, H. (2007). Biosorption of copper(II) from aqueous solutions by green alga Cladophora fascicularis. Biodegradation, 18, 393402 . 
Garnham, G. W., Codd, G. A., \& Gadd, G. M. (1992). Kinetics of uptake and intracellular location of cobalt, manganese and zinc in the estuarine green alga Chlorella salina. Applied Microbiology and Biotechnology, 37, 270-276.

Gong, R., Ding, Y., Liu, H., Chen, Q., \& Liu, Z. (2005). Lead biosorption and desorption by intact and pretreated Spirulina maxima biomass. Chemosphere, 58, 125-130.

Gupta, V. K., \& Rastogi, A. (2008). Equilibrium and kinetic modelling of cadmium(II) biosorption by nonliving algal biomass Oedogonium sp. from aqueous phase. Journal of Hazardous Materials, 153, 759-766.

Gupta, V. K., Rastogi, A., Saini, V. K., \& Jain, N. (2006). Biosorption of copper(II) from aqueous solutions by Spirogyra species. Journal of Colloid and Interface Science, 296, 59-63.

Han, X., Wong, Y. S., \& Tam, N. F. Y. (2006). Surface complexation mechanism and modeling in $\mathrm{Cr}(\mathrm{III})$ biosorption by a microalgal isolate, Chlorella miniata. Journal of Colloid and Interface Science, 303, 365-371.

Jennings, J. R., \& Rainbow, P. S. (1979). Accumulation of cadmium by Dunaliella tertiolecta Butcher. Journal of Plankton Research, 1, 67-74.

Kaduková, J., \& Virčíková, E. (2005). Comparison of differences between copper bioaccumulation and biosorption. Environment International, 31, 227-232.

Leborans, G. F., \& Novillo, A. (1996). Toxicity and bioaccumulation of cadmium in Olisthodiscus luteus (Raphidophyceae). Water Research, 30, 57-62.

Lee, J. G., \& Morel, F. M. M. (1995). Replacement of zinc by cadmium in marine phytoplankton. Marine Ecology Progress Series, 127, 305-309.

Maeda, S., \& Sakaguchi, T. (1990). Accumulation and detoxification of toxic elements by algae. In I. Akatsuka (Ed.), Introduction to Applied Phycology (pp. 109-136). The Hague: SPB Academic.

Maeda, S., Mizoguchi, M., Ohki, A., Inanaga, J., \& Takeshita, T. (1990). Bioaccumulation of zinc and cadmium in freshwater alga, Chlorella vulgaris. Part II. Association mode of the metals and cell tissue. Chemosphere, 21, 965-973.

Matheickal, J. T., Yu, Q., \& Woodburn, G. M. (1999). Biosorption of cadmium(II) from aqueous solutions by pre-treated biomass of marine alga Durvillaea potatorum. Water Research, 33, 335-342.

Matsunaga, T., Takeyama, H., Nakao, T., \& Yamazawa, A. (1999). Screening of marine microalgae for bioremediation of cadmium-polluted seawater. Journal of Biotechnology, 70, 33-38.

Monteiro, C. M., Marques, A. P. G. C., Castro, P. M. L., \& Malcata, F. X. (2009). Characterization of Desmodesmus pleiomorphus isolated from a heavy metal-contaminated site: biosorption of zinc. Biodegradation, 20, 629-641.

Moreno-Garrido, I. (2008). Microalgae immobilization: current techniques and uses. Bioresource Technology, 99, 39493964.

Oliveira, R. S., Dodd, J. C., \& Castro, P. M. L. (2001). The mycorrhizal status of Phragmites australis in several polluted soils and sediments of an industrialised region of Northern Portugal. Mycorrhiza, 10, 241-247.

Özer, A., Özer, D., Dursun, G., \& Bulak, S. (1999). Cadmium (II) adsorption on Cladophora crispata in batch stirred reactors in series. Waste Management, 19, 233-240.
Pawlik-Skowrońska, B., Pirszel, J., \& Skowronski, T. (1998). The sorption and removal of heavy metals by algal biomasses. Oceanological Studies, 1, 91-103.

Pérez-Rama, M., Alonso, J. A., López, C. H., \& Vaamonde, E. T. (2002). Cadmium removal by living cells of the marine microalga Tetraselmis suecica. Bioresource Technology, 84, 265-270.

Price, N. M., \& Morel, F. M. M. (1990). Cadmium and cobalt substitution for zinc in a marine diatom. Nature, 344, 658660.

Radway, J. C., Wilde, E. W., Whitaker, M. J., \& Weissman, J. C. (2001). Screening of algal strains for metal removal capabilities. Journal of Applied Phycology, 13, 451-455.

Rangsayatorn, N., Upatham, E. S., Kruatrachue, M., Pokethitiyook, P., \& Lanza, G. R. (2002). Phytoremediation potential of Spirulina (Arthrospira) platensis: biosorption and toxicity studies of cadmium. Environmental Pollution, $119,45-53$.

Sakaguchi, T., Tsuji, T., Nakajima, A., \& Horikoshi, T. (1979). Accumulation of cadmium by green microalgae. European Journal of Applied Microbiology and Biotechnology, 8, 207-215.

Sánchez, A., Ballester, A., Blázquez, M. L., González, F., Muñoz, J., \& Hammaini, A. (1999). Biosorption of copper and zinc by Cymodocea nodosa. FEMS Microbiology Reviews, 23, 527-536.

Schmitt, D., Müller, A., Csögör, Z., Frimmel, F. H., \& Posten, C. (2001). The adsorption kinetics of metal ions onto different microalgae and siliceous earth. Water Research, 35, 779785 .

Scragg, A. H., \& Bonnet, C. (2002). Inhibition of microalgal growth by silver nitrate. Biotechnology Letters, 24, 169172.

Sheng, P. X., Ting, Y.-P., Chen, J. P., \& Hong, L. (2004). Sorption of lead, copper, cadmium, zinc, and nickel by marine algal biomass: characterization of biosorptive capacity and investigation mechanisms. Journal of Colloid and Interface Science, 275, 131-141.

Sheng, P. X., Ting, Y.-P., \& Chen, J. P. (2007). Biosorption of heavy metals ions $(\mathrm{Pb}, \mathrm{Cu}$ and $\mathrm{Cd})$ from aqueous solutions by the marine algae Sargassum sp. in single- and multiple-metal systems. Industrial and Engineering Chemistry Research, 46, 2438-2444.

Singh, R., \& Prasad, B. B. (2000). Trace metal analysis: selective sample (copper II) enrichment on an AlgaSORB column. Process Biochemistry, 35, 897-905.

Solisio, C., Lodi, A., Soletto, D., \& Converti, A. (2008). Cadmium biosorption on Spirulina platensis biomass. Bioresource Technology, 99, 5933-5937.

Torres, E., Cid, A., Herrero, C., \& Abalde, J. (1998). Removal of cadmium ions by the marine diatom Phaeodactylum tricornutum Bohlin: accumulation and long-term kinetics of uptake. Bioresource Technology, $63,213-220$.

Tüzün, İ., Bayramoğlu, G., Yalçin, E., Başaran, G., Çelik, G., \& Arica, M. Y. (2005). Equilibrium and kinetic studies on biosorption of $\mathrm{Hg}(\mathrm{II}), \mathrm{Cd}(\mathrm{II})$ and $\mathrm{Pb}$ (II) ions onto microalgae Chlamydomonas reinhardtii. Journal of Environmental Management, 77, 85-92.

Tukaj, Z., Baścik-Remisiewicz, A., Skowroński, T., \& Tukaj, C. (2007). Cadmium effect on growth, photosynthesis, ultra- 
structure and phytochelatin content of green microalga Scenedesmus armatus: a study at low and elevated $\mathrm{CO}_{2}$ concentration. Environmental and Experimental Botany, 60, 291-299.

Vannela, R., \& Verma, S. (2006). $\mathrm{Co}^{2+}, \mathrm{Cu}^{2+}$ and $\mathrm{Zn}^{2+}$ accumulation by Cyanobacterium Spirulina platensis. Biotechnology Progress, 22, 1282-1293.
Yan, H., \& Pan, G. (2002). Toxicity and bioaccumulation of copper in three green microalgal species. Chemosphere, 49, 471-476.

Yoshida, N., Ikeda, R., \& Okuno, T. (2006). Identification and characterization of heavy metal-resistant unicellular alga isolated from soil and its potential for phytoremediation. Bioresource Technology, 97, 1843-1849. 